\title{
Mundos do Trabalho: desafios e perspectivas
}

Mesmo em tempos normais, o trabalho de editoria não é fácil. Ele envolve um complexo conjunto de procedimentos acadêmicos e técnicos e rigorosa atenção ao cronograma de atividades, um calendário que não conhece períodos de férias ou mesmo pausas para finais de semana ou feriados. A rotina de receber e fazer a primeira triagem dos manuscritos com vistas a verificar seu enquadramento no foco e escopo da revista, submetê-los à avaliação cega de mérito pelos pares, encaminhálos para a revisão linguística e editoração não pode sofrer descontinuidade. Qualquer atraso ou erro pode significar um prejuízo objetivo e/ou subjetivo para o periódico e para seus autores e leitores. Publicar artigos de excelência é fundamental, mas é apenas uma parte da tarefa. É preciso que o periódico mantenha seus textos catalogados em indexadores de metadados, buscadores e bibliotecas virtuais que garantam uma boa inserção dos autores nas mais importantes redes intelectuais nacionais e internacionais. Além disso, é necessário que a revista seja visualmente atraente e que sua leitura seja aprazível.

A implementação de mudanças que possibilitem alcançar esses objetivos depende de precisão nos cálculos dos recursos materiais e humanos disponíveis para a execução do trabalho. Afinal, erros de projeto em publicações científicas são difíceis de serem revertidos. Em momentos como o que estamos vivendo, marcado pela redução drástica dos investimentos públicos em educação e ciência e pela hostilidade governamental aos intelectuais e ao pensamento crítico, tornase ainda mais difícil e arriscado promover grandes mudanças. Quando o leitor olha para a capa de um periódico e escolhe um artigo no sumário, muitas vezes ele desconhece o grande volume de recursos materiais e de trabalho intelectual e manual despendidos pelos diversos profissionais e instituições envolvidos no processo de produção daquele resultado, verdadeiro repositório de sinergia entre editores, membros do conselho editorial, autores, avaliadores e leitores, além dos financiadores do empreendimento e dos prestadores de serviços.

A editoria de Mundos do Trabalho realizou estudos, calculou riscos e potenciais ganhos e decidiu promover importantes e variadas mudanças em 2019, momento em que a revista completou 10 anos de existência e 20 números publicados. A mais radical foi a substituição da periodicidade semestral pelo sistema de publicação contínua, com apenas um volume anual. Essa mudança exigiu um esforço especial, 
já que a quantidade de manuscritos a serem publicados entre janeiro e dezembro de cada ano é muito maior. Para que se tenha uma ideia, o volume 11 (2019) traz nada menos que 14 textos na seção Artigos e 15 nos dois Dossiês. O primeiro dossiê (Trabalhadores e Segunda Guerra Mundial) tem uma apresentação e seis artigos e o segundo (Beatriz Ana Loner: mundos do trabalho e pós-abolição) tem uma apresentação e sete artigos. Há também uma resenha. Portanto, são 30 textos. É, sem dúvida, um padrão bem distinto do usual.

Como consequência, os custos financeiros e a quantidade de pessoas envolvidas no processo de avaliação, revisão e editoração das mais de 700 páginas que compõem o presente volume são bem maiores. Por outro lado, o sistema de publicação contínua permite a divulgação de pesquisas de modo muito mais célere e prático, já que os artigos são avaliados, editorados e publicados de modo independente, dispensando-se o fechamento de um número para disponibilizá-los para leitura e discussão.

Como parte do esforço de ampliação de sua inserção internacional, desde 2018 Mundos do Trabalho tem publicado artigos e resenhas de autores estrangeiros em inglês e espanhol. Como forma de garantir que um público maior leia tais textos, alguns desses artigos publicados em inglês também foram traduzidos e oferecidos ao público em português na mesma edição.

Outra novidade foi a adoção de um novo projeto gráfico. Ele se destaca não apenas pela belíssima capa do volume, mas também pelos elementos gráficos do miolo, com o uso de um tipo de fonte que possibilita a acessibilidade para deficientes visuais. Por fim, a editoria de Mundos do Trabalho tem envidado esforços contínuos visando inserir a publicação em novos indexadores de metadados, buscadores e bibliotecas virtuais como forma de garantir maior inserção e impacto de seus artigos e autores.

ARevista Mundos do Trabalho registra aqui seus agradecimentos à Universidade Federal de Santa Catarina (UFSC), por hospedá-la em seu Portal de Periódicos desde 2009, e ao Programa de Pós-Graduação em História da Universidade do Estado da Bahia (UNEB), pelo apoio financeiro que the concede desde 2014.

Equipe Editorial, 13 de dezembro de 2019. 